\title{
Technology and the Language Teacher
}

\author{
Taslima Irine Ivy*
}

\section{Introduction}

Today is the world of Facebook, Twitter, MySpace, Google, Yahoo, I-pods, I- pads. Gadgets reign supreme even in a developing country like Bangladesh (e.g. cell phones) and so technology is fused in every part of our lives, in fact, "technology is no longer a tool to create an alternative environment- it is THE environment" (Gupta, 2010: 68). Academic institutions are, therefore, expected to prepare students for a technological era that awaits them. As an inevitable consequence, there is an expectation from administrators and students alike that a teacher will use technology to sophisticate teaching. As language teaching professionals our life is also intertwined with technology: for administrative purposes, materials development and storage, grading, professional communication, photocopies, scanning and so on. Technology, whether for the classroom or for official purpose, has to be implemented for its pedagogical value and relevance-not just to jump into the bandwagon. This article is a brief overview of technologies and tools considered necessary for the language teacher of today especially in the context of Bangladesh. It also tries to summarize dominant emerging trends in the field of technology enhanced language learning.

\section{Technology: Professional Purposes}

Today's technical workplace is quite a different picture from even 20 years ago. Teachers now not only need pedagogical knowledge but also an elementary understanding of the workings of computers, use word processing program, understand the concept of a file and storage media, use a web browser effectively, know

\footnotetext{
${ }^{*}$ Lecturer, Department of English, University of Dhaka.
} 
how to make powerpoint slides and on goes the list. According to Jones (2002: 10), "Today, such skills are normally a pre-requisite for success in higher education. Even for accessing resources on the internet and publishing".

However, there may be a washback effect due to the expectations imposed by some teachers' workplace. Allan (2009: 26) discusses the technological overload on teachers nowadays and adds that "This circumstance is exacerbated by the absence of a comprehensive training scheme, lack of practice time, and deficiencies in educational technology support, staffing and planning. Instructors are often left to their own devices, and are expected to identify technology skill deficiencies, as well as troubleshoot hardware and software problems".

Stevens (2010) has refuted this debate by saying, "All professionals suffer from technology overload. This load is not as heavy for teachers as it is in other professions, e.g. medical, engineering, chemistry, physics. Yet, teachers of students going into these professions are responsible for training students how to learn" and as such educators need to face the changes technology has brought to the workplace and not shy away.

Academic institutions in Bangladesh are not overloaded with technology and there are no training schemes for language teachers to learn the use of whatever technology there might be. Teachers are expected to know these already or get help from their colleagues. Fortunately, teachers are lifelong learners and training courses on technology are abundant.

Following is an inventory of technological options teachers may take advantage of at the workplace:

Internet: In this world, it is a sin not to explore the possibilities of the internet. The internet provides instant access to journals, calls for papers, information on higher education and jobs, professional organizations/networks (LinkedIn), prepared lesson plans, powerpoints, up to date theory and trends. The list is endless with just one click away. Teachers should be equipped with the necessary skills to track and sort out these resources. 
Multimedia Presentation: Powerpoint presentations can be used by teachers to present organized lectures, aid 'visual' and inattentive learners and prepare students for their professional life. According to Jones (2002),

Using presentation software such as Microsoft PowerPoint generally needs little training in its use. Templates make it very easy to develop a good looking slide show. Media incorporation is straightforward as well; graphics, audio, and video can be added from pull-down menus.

Office Applications: Creating worksheets, handouts, posters, newsletters, reports, official correspondence, spelling and grammar checking, concordancing, collaborative writing, referencing, presenting research data etc. can all be done efficiently with these programs. "Most teachers are proficient with the word processor but spreadsheets, databases and mastery in advanced softwares like Microsoft excel. require concerted effort on the part of the educator" (Allan, 2010: 23)"

Shared Drives: In a setting where a computer is shared by different teachers each person is usually allotted a personal account. Personal data are stored and retrieved in personal accounts as well as "Z $Z$ Drives" or "shared drives" or "common-drives". Teachers have to master these pathways. Academics should also familiarize themselves with the institutional website in order to access administrative information like student withdrawals, drop outs, class schedules, exam schedules, rescheduled classes, submitting grades etc.

Audiovisual Equipment: These days most classrooms are equipped with an audiovisual component system which can be linked to a laptop/ USB device. Educationists should aim to master the basic operational systems. This component system requires high technical skills to alter or restore settings or regain connection after power supply cut out. Waiting for staff to come and waiting for the system to be reset can considerably disrupt the pace of the lecture.

Images and soundtracks: Sometimes teachers may want to add visuals, soundtracks, videos and animations to materials/worksheets. These materials are not always available in 
perfect form and therefore, require adapting, editing, cuttingpasting, resizing files, altering resolutions, touch ups with tools etc. This is yet another sector in itself and teachers have to acquire skills for the achievement of optimum results.

Backing up and protecting data: Storing all data in only one place may give rise to complexities in the long run. First, running out of space and then a possibility of losing the device or simply a virus attack can take away all that hard work with nothing left to do. We have to make at least one backup copy. Protecting data on computers is done with Norton, AVG or MacAfee. Teachers also have to be able to detect threats and delete or uninstall virus affected files.

Communication: E-mail communication is a most common practice and, therefore, it is an absolute necessity to learn operating features as opening and sending personal/ group mails, adding/deleting/finding contacts from the contact list, attaching/downloading files at a minimum.

Replicators: Photocopiers can make all handouts cheaply available to students while printers are indispensible for printing downloaded materials. Although photocopy is usually done by the office staff, printing and scanning job are left on the teacher. Using these are not that complicated.

\section{Technology: Educational Purposes}

Literature on using technology in the language classroom has brought out advantages (Salaberry, 1999; Rost 2002; Lee 2000; Taylor and Gitsaki, 2003 cited in Lai and Kritsonis 2006) and disadvantages too in terms of cost, time and uncertain results (Warschauer and Meskill, 2000), inability to deal with speaking, unexpected situations etc.

Warschauer and Meskill (2000: 5), however, have supported the use of technology despite all disadvantages for two reasons. Firstly, using computers for education is comparable to using books or print and if there is no debate on the prior, debate on using the latter is futile. Secondly, students need to learn the language of technology (e-mails, conducting web researches, netiquette) to 
survive in times awaiting them and so, technology has to be used "as a legitimate medium of communication in it's own right".

Studies carried out by Fischer Family trust (2002), Impa CT2 (Becta, 2001), Chong et.al (2005) have all brought out a remarkable influence of using technology in education. Case studies cited by Warschauer and Meskill (2000: 13) on foreign language instruction, ESL instruction \& Bilingual instruction proved that "appropriate use of new technologies allows for a more thorough integration of language, content and culture than ever before and provide students with unprecedented opportunities for autonomous learning." Rost (2002) too has discussed how computer assisted learning allow learners more independence.

'Exposure to authentic materials' is another boon of being able to integrate technology efficiently in EFL classrooms. Sawhil (2008) comments on how blogs, wikis and even Voice-over-IP tools like Skype can help educators. Firstly, they allow students a means to continue to connect with the language outside the classroom and secondly, these tools offer students the possibility of authentic, dynamic contact with natives, and therefore, the challenge of putting classroom knowledge to the test in a context that mirrors the reality awaiting them outside the Academy.

Lai and Kritsonis (2006) have pointed out how technology can promote experiential learning and practice learning. Experiential learning theory is about extracting meaning, making sense of information, relating it to real life \& understanding the world through re-interpreting knowledge-which is exactly what the use of social connecting sites do. They also believe that shy or inhibited learners can be greatly benefited through the individualized learning environment while more able learners can proceed at their own rate.

The integration of technology is stressed repeatedly to prepare students for a world in which they will be redundant without such knowledge. According to Sawhil (2008: last para), "Our emerging role as teachers and technologists in the 21 st century is to prepare ourselves, our colleagues, our schools and our classrooms for the linguistic and cultural realities of the teaching in a world where everyone and everything is connected, or 
"intertwingled". Duderstadt et al. (2002, cited in Sawhill, 2008) while describing the current state of technology in higher education wrote: "the traditional classroom paradigm is being challenged today, not so much by professors... but by our students." Importance placed on intercultural communication is higher than ever before. In Warschauer and Meskill's (2000: 10) words:

The internet is a great opportunity to harness such skills by opening up new worlds. New communication technologies are part of the broader ecology of life, at the turn of the century. Much of our reading, writing and communicating is migrating from the other environments (print, telephone etc.) to the screen. In such a context, we can no longer think only about how we use technology in the classroom but also the types of language (e-mails, conducting web research etc) students need to learn in order to communicate effectively via computer.

The following trends have started to emerge in language classrooms all over the world. However, research on integrating technology in the Bangladeshi educational system is relatively scarce (one attempt is being taken up by English in Action ${ }^{1}$ ) and more case studies are needed to come to an appropriate conclusion about the nature and cost of technology apt for EFL classrooms in Bangladesh.

Computer Assisted Language Learning (CALL): CALL embraces a wide range of ICT applications and approaches to teaching and learning foreign languages. They are:

- CALL drill-and-practice

${ }^{1}$ English in Action (EIA) is a nine-year (2008-2017) language education Programme funded by UKaid from the Department for International Development (DFID) to develop communicative English language skills in Bangladesh.The program is currently being piloted in 24 upazillas, covering 346 schools (out of which 231 are primary) and 753 teachers including 61 teacher facilitators . To enhance the quality of learning in schools, EIA is using a combination of existing and new methods, including interactive audio technology, mobile-technology, print and ICT based materials. Research and baseline study reports of EIA's findings can be found on the website www.eia.bd.com. 
- Web-based distance learning: A type of education. where students work on their own at home or at the office and communicate with faculty and other students via e-mail, electronic forums, videoconferencing, chat rooms, bulletin boards, instant messaging and other forms of computerbased communication.

- Use of corpora: Corpora, plural term of a 'corpus', refer to electronic authentic language databases. Language corpora can be either collections of written or spoken texts and as such students can search and learn not only words but also the appropriate context in which the words might appear. Learners, therefore, are involved in a more speedy and efficient language learning experience. These are available on the internet or can be installed in computers as software programs.

- Concordancing software: It helps teachers/ students to search through texts or corpora to look for actual usage of a word rather than just definition. For example, collocational meanings like "large box" vs. "big box" or grammatical features like "was going" vs "used to go".

- Multimedia Simulation software : Learners enter computerized microworlds with exposure to language and culture in a meaningful audio visual context.

- Interactive whiteboards: An interactive whiteboard (IWB) is a large interactive display that connects to a computer and projector. The software supplied with the interactive whiteboard will usually allow the teacher to keep notes and annotations as an electronic file for later distribution either on paper or through a number of electronic formats.

In addition, some interactive whiteboards allow teachers to record their instruction as digital video files and post the material for review by students at a later time.

- Computer Mediated Communication (e.g. Daedalus interchange): Writing programs where students communicate with tools like instant messaging in the class e-mails/conferencing in small groups out of class. Long distance projects have been organized for joint exploration of culture, social conditions, film or literature which have often resulted in collaborative publication. (Cummins and 
Sayers, 1997 in Warschauer and Meskill, 2000) Textreconstruction software: Teachers can easily and quickly create re-arranged texts or cloze exercises from any word processed passage. Students can use hints provided by the computer.

- Mobile-assisted language learning (MALL): Mobile Assisted Language Learning (MALL) describes an approach to language learning that is assisted or enhanced through the use of mobile devices such as mobile phones (cellphones), MP3 and MP4 players, and devices such as the iPhone or iPad. With MALL, students are able to access language learning materials and to communicate with their teachers and peers at any time, anywhere.

Advantages of CALL have been spelled out in terms of high motivation, authentic communication, learner autonomy, cooperative learning, neutrality and so on.

Electronic Whiteboards: The recent teacher favorite is the electronic whiteboard or the smartboard. The electronic whiteboard can be linked with student laptops. The teacher's writings on the whiteboard can be directly downloaded by the students and the students can project their computer screen on the board interact. Although it is a very interesting add on to the classroom, implementation is costly and as such is not feasible in the context of Bangladesh.

Accessing resources and publishing on the World Wide Web: Students use web pages as authentic materials for conducting research on culture and current events (Osuna and Meskill 1998), or for gathering materials for class projects and simulations. Students can publish their writings on the web and thus write for the real audience. Teachers can create in- class online newsletters or help students contribute to international web magazines which include articles from students around the world (Shetzer 1995).

Web 2.0: Web 2.0 refers to the emergence of a set of applications on the web which facilitate a more socially connected web where everyone is able to add to and edit information online (Anderson 2007). Whereas Web 1.0 was dominated by content provided in static pages, Web 2.0 applications have democratized the web by 
prioritizing user-generated content, ownership and social connectivity. The following sections will explore how these technologies can be used to enhance the language-learning process:

1. Blogs: A blog is a web application that displays a series of entries in reverse chronological order, with a time and date stamp for each entry. Blogs also include a facility to respond to blog posts using comments. Campbell (2003) identifies three potential uses for the blog in the language classroom:

a. The tutor blog: daily reading practice for learners, online verbal exchange using comments, class information, resource for self-study.

b. The learner blog: Students get writing practice, develop a sense of ownership, and whatever they write can instantly be read by anyone else and, due to the comment features of the software, further exchange of ideas is promoted.

c. The class blog: Students can create a free-form bulletin board, interact in an international classroom language exchange, or a project-based language learning exercise, where students can develop writing and research skills by creating an online resource.

Research by Thorne et al (2005, cited in Thorne and Payne 2005) suggests that language students prefer blogging to traditional essays. Students also reported frequently looking back over their own and other students' earlier blog postings, and majority noticed significant progress in their writing over time.

2. Wiki: Wiki is an online software for creating simple websites which support collaborative writing, the most wellknown of which is Wikipedia. While blogs tend to be written by an individual, and are therefore personal in nature, wikis are more likely to be the result of a collaborative effort. Students build a sense of community by collaborating on a shared goal, and they learn from observing the communal work being drafted, refined, and 
finalized. Accountability is increased through exposure to peers or the wider internet audience (Newstead, 2007).

3. Podcasting: A broadcast available on the Internet anytime for downloading to a portable media player, computer, mobile etc. Podcasting can be used in the following ways by the language learners or teachers:

- to listen to varied sources of authentic input - radio broadcasts (BBC radio podcasts)

- to make students create their own podcasts in the foreign language

- to listen to 'semi-authentic' language (Robin 2007) created specifically for language learners, who would find authentic texts too stretching (e.g. BBC World English 'Real English' podcast)

- to subscribe to language courses (e.g. Chinese Pod, Spanish Pod), which can conveniently be listened to at any point in the day (e.g. in the car, on the train)

Podcasting can be very motivating, especially if the students are aware of an audience. The attention to detail then is much greater (Stanley, 2006).

4. Social Networking: Students spend most of their free time on social networking sites (Myspace, Twitter, Facebook ). Therefore, these sites can be a very good platform for extensive writing, reading and interaction. Moreover, they are enjoyable, highly motivating and lower anxiety generators than the formal classrooms (Kern 1995, cited in Thorne and Payne 2005). Integration of social network based activities with regular classes will provide optimum results.

Virtual learning environments (VLE): In 3D Virtual worlds (e.g. second life) users assume an online identity - an "avatar" - to represent themselves. The avatar can walk, run, fly, shop, own virtual pets, communicate with other avatars through chat, instant messaging and actually talking online. It can be used for authentic interaction with target language speakers. Second Life claims to offer limitless academic possibilities (MIT virtual classrooms, Notre Dame distance learning). A study on language learning in 
VLE's by Peterson (2006) found that use of avatars made the students feel more involved in the interaction, was more stimulating and enjoyable.

Learning Management System or LMS: A learning management system (LMS) is software for delivering, tracking and managing training/education. A learning management system (Nicenet, Blackboard, Moodle) is a step ahead the static classroom website providing students options to download/upload files, participate in chat/discussion boards, take assessments and contact the teacher/classmates. If the instructor posts samples of student work, students and parents can see how other classmate performances and have a clearer idea of academic expectations. The use of an LMS gives the teacher the opportunity to promote classroom activities (by placing reusable learning documents, video, and practice exercises on the system) and course expectations (Waters, 2007).

\section{Problems}

Using technology in the classroom is not without difficulties. Teachers may face various problems such as:

1. A major barrier a teacher in Bangladesh may face while attempting to use technology in the classroom or workplace is lack of effective training. Without thorough understanding of the technology at hand it will be impossible to bring out optimum results.

2. Issues such as tracking down appropriate information, misspelt addresses, slow connections, blocked access, system crashes, loose wires, out-of-date plug- ins, out of date websites, lack of administrative privilege and antiquated hardware can ensure that many EFL instructors avoid using the Web.

3. Sharma (2009) points out the deficiency of theoretical basis for using technology in the following words:

The innovators innovate, and later, pedagogy plays catchup, as teachers try things out. The world of theory (of 
evidence and research) is, arguably, lagging behind what is happening in the classrooms.

For example, Twitter will probably have an improved version by the time case studies have justified whether or not the present version has value.

4. Implementing new technologies require financial expenses for hardware, software, training and staffing. Not all students have technology at home so they may not be able to submit homework. It is not always possible to fund language programs with such high cost, especially in the developing countries. Therefore, most of the technologies remain 'distant dreams' to a good number of teachers in our country. Availability of high quality software and hardware can also be a pressing problem for willing professionals.

5. The educator needs to invest time to learn how to master the technology, think about how to implement it in the classroom and also evaluate whether all the hassle is worth it at all. This is a potential disadvantage as there is often uncertainty as to whether a new technology will actually prove to be a blessing or a curse.

6. Arguments are raging about electronic translators and synonym generators. According to Sharma (2009), "These provide many benefits, yet, when used for production, they seem to encourage the selection of the wrong word in English."

7. With thousands of academic essays available online there has been a great rise in plagiarism.

8. The problem with Internet-based multimedia is that images, sounds, and videos need relatively large files that take a long time to download. This waiting period slows down the interactions between the student and the materials, wastes time, and creates an uncomfortable impression. 
9. Technology always has the possibility of malfunctioning. Moreover, in Bangladesh there is the constant threat of power failure posing the question of whether or not a plan can be smoothly carried out.

\section{Suggestions}

Some suggestions for successfully integrating technology in the language classroom are as follows:

1. Sharma (2009) discusses the importance of going beyond the 'wow' factor and thinking about pedagogical reasons for using any technology. So it is not the 'video' per se which could enhance learning, but how it is used.

2. For teachers needing training in the use of general purpose software, electronic tutorials (tutorial CDs, Websites such as Smartforce) have become widely available.

3. According to Jones (2002),

The MP3 file format has moved from the darling of teenage Napster users to being a widely used format in education. Media sites often supply audio files in a variety of formats including MP3. Using MP3 files, rather than cassettes to play audio in the classroom offers the advantage of instant replay and fast searching.

4. The number of websites available on the internet and the amount of information may be overwhelming. Jarvis (2011) suggests the following criteria to evaluate any website/material for possible usage:
a) Language learning potential
b) Meaning focus
c) Learner fit
d) Authenticity
e) Positive impact
f) Practicality

5. Jarvis also (2011) suggests that the websites containing "edu" or "ac" in their addresses suggest they are academic 
institutions and hence are reliable. Addresses with the word "org" are of organizations and therefore, are quite reliable. The addresses ending in "com" are commercial websites and as a result necessitate evaluation on the teacher's side before downloading information.

6. Plagiarism detectors (turn-it-in, iThenticate, googling up) can detect plagiarized essays for teachers.

7. Teachers always need a plan B to back up power failure or malfunction. Powerpoint slides or examination question papers should be printed and photocopied well in advance. Important material should not be stored in the $\mathrm{C}$ - drive (or desktop) which is the most perishable drive.

8. Some useful sites for ESL learners and teachers: http://www.teflclips.com (readymade video lessons with worksheets)

http://www.teachingenglish.org.uk (view the blogs and participate in discussions)

http://www.tesolacademic.org (for webcasts on latest research) (from Jarvis, 2011)

- Materials:

Online writing: http://www.owl.englis.purdue.edu

Younger learners: http://www.linguistics-funland

ESL: http://www.esolcourses.com/

http://www.manythings.org/

Grammar: http://www.ego4u.com/

Pronunciation:

http://cambridgeenglishonline.com/Phonetics_Focus/

listening :http://www.esl-lab.com/index.htm

lessons: http://www.tefl.net

- Organizations:

IATEFL: www.iatefl.org

TESOL: www.tesol.edu 
British

Council:

www.britcoun.org/english/index.htm

- Journals:

TESOL

quarterly:

www.tesol.org/pubs/magz/tq.html (subscription

necessary)

Language in India: www.languageinindia.com

(Language issues in the sub-continent).

Language \& Technology: http://llt.msu.edu

Asian EFL Journal: http://www.asian-efljournal.com/

Journal of Asia TEFL:

http://www.asiatefl.org/journal/journal1.html

- Powerpoints and ideas:

Pete's powerpoint station: www.pppst.com (free powerpoints)

Dave's ESL Café: www.eslcafe.com (ESL games, international jobs)

- Upcoming Conferences:

http://www.conferencealerts.com/language.htm

\section{Conclusion}

Technology is here to make our lives simplified not complicated. Meyer (2009) commented that "Technology is here to stay- nobody can deny this... and blind resistance will take us nowhere. On the other hand, uncritical adoption of technology might lead to unprincipled teaching- which in my opinion is the greatest sin of all." Proper training combined with in-depth evaluation of the specific technology is desirable in one's own context to spell out an appropriate technological environment. Only then can we keep pace with this ever changing ever evolving aspect of teaching and be prepared for future implications. 


\section{References}

Allan, J. 2009. Are Language teachers Suffering from Technology Overload? Perspectives, 16 (2), 23-26.

Anderson, P. 2007. What is Web 2.0? Ideas, technologies and implications for education. JISC techwatch report. Retrieved from http:// www.jisc.ac.uk/media/documents/techwatch/tsw0701b.pdf on 12th May, 2011.

Becta 2001. Schools of the Future- Achieving Today. A report of the DfEE, Becta. Retrieved from www.becta.org.uk

Campbell, A. 2003. Weblogs for Use with ESL Classes. The Internet TESL Journal, 9 (2), Retrieved from http://iteslj.org/ Techniques/Campbell-Weblogs.html on 25th May, 2011.

Cummins, J. \& Sayers, D. 1997. Brave New Schools: Challenging Cultural Illeteracy. New York: Praeger.

Duderstadt, J. J., Atkins, J. J. \& Van Houweling, D. E. 2002. Higher Education in the Digital Age: Technology Issues and Strategies for American Colleges and Universities. American Council on Education /Praeger series on higher education. Westport, Conn: Greenwood Press.

Fischer Family Trust Report 2002. Retrieved from http://www.fischertrust.org/ict_main.aspx on 22 $2^{\text {nd }}$ May, 2011

Gupta, R. 2010. Using Technology in the English Language Classroom. Language in India, 10 61-76.

Hasselgård. H. 2001. Corpora and their use in research and teaching. Retrieved from http://folk.uio.no/hhasselg/UV-corpus.htm on $15^{\text {th }}$ June, 2011.

Jarvis. H. 2011. Websites for Language Teachers and learners: what's out there and how good they? Workshop conducted at the $5^{\text {th }}$ BELTA International Conference, 2011 Dhaka, Bangladesh. Handout retrieved from www.tesolacademic.org on $24^{\text {th }}$ May, 2011.

Jones, B.G. 2002. Technology for Prospective Language Teachers. Language Learning \& Technology ,6 ,10-14. Retrieved from http://www. llt.msu.edu/vol6num3/pdf/emerging.pdf on $20^{\text {th }}$ January, 2011. 
Lai, C.C. \& Kritsonis, W. A. 2006. The Advantages and Disadvantages of Computer Technology In Second Language Acquisition. National Journal for Publishing And Mentoring Doctoral Student Research, 3 (1), Retrieved from http://www.faculty.ksu.edu.sa/.../CALL\%20 Advantages\%20and\% 20disadvantages.pdf on $22^{\text {nd }}$ February, 2011.

Lee, K.W. 2000. English teachers' barriers to computer assisted language learning. The Internet TESL Journal, Retrieved from http:// www.4english.cn/englishstudy/xz/thesis/barrir

Mayer, H. (2009, April 10). Controversies in using technology. Message posted to http:// http://www.teachingenglish.org.uk /think/articles/controversies-using- technology- language-teaching. Retrieved on $26^{\text {th }}$ January, 2011.

Newstead, Helen 2007. Web 2.0/Language Learning. Retrieved from http:// web20andlanguagelearning.wikidot.com/about on $29^{\text {th }}$ March, 2011.

Osuna,M., \& Meskill, C. 1998. Using the World Wide Web to integrate Spanish language and Culture: A pilot. Language Learning and Technology Journal, 1 (2).

Peterson, M. 2006. Learner Interaction Management in an Avatar and Chat-based Virtual World. Computer Assisted Language Learning 19(1), 79-103.

Robin, R. 2007. Commentary: Learner-based Listening and Technological Authenticity. Language Learning \& Technology 11(1), 109-115. Retrieved from http://llt.msu.edu/vol11num1/ robin/default.html on $17^{\text {th }}$ May, 2011.

Rost, M. 2002. New Technologies for language education: Opportunities for professional growth. Retrieved from www.longman.com/ae/multimedia/pdf/MikeRost_PDF.pdf

Salaberry, R. 1999. CALL in the year 2000: Still developing the research agenda. Language Learning and Technology, 3 (1), 104107.

Sawhill, B. 2008. The Changing Role of the Language Teacher/Technologist.The IALLT Journal, 40 (1), retrieved from http://ialltjournal.org/apa/doc.Xhtml?id= iallt_40_01_Sawhill on $22^{\text {nd }}$ April, 2011. 
Sharma, P. 2009. Controversies in using technology in language teaching. Retrieved from http:// http://www.teachingenglish.org.uk/ think/articles/controversies-using-technology-language-teaching on $22^{\text {nd }}$ May, 2011.

Shetzer, H. 1995. EX*CHANGE: Electronic, Xross Cultural, Hypertextual Academy of Non-native Gatherings in English. In Warschauer, M. (ED.).Virtual connections: Online activities and projects for networking language learners, (pp.191-197). Honolulu, HI: University of Hawai'i, Second Language Teaching and Curriculum Center.

Stevens, V. 2010. How can teachers deal with technology overload? Retrieved from http://multiliteracies.ning.com/profiles/blogs/howcan-teachers-deal-with\%20 on $25^{\text {th }}$ May, 2011.

Taylor,R. and Gitaski, C. 2003. Teaching well and loving it. In Fotos and Browne (Ed.), New perspectives on CALL for second language classrooms (pp.131- 147). Mahwah, NJ: Lawrence Erlbaum Associates.

Thorne, S. L., and Payne, J. S. 2005. Evolutionary Trajectories, Internet-mediated Expression, and Language Education. The CALICO Journal 22, Retrieved from http:// language.la.psu.Edu/\%7Ethorne/thorne_payne_calico2005.pdf on $15^{\text {th }}$ April, 2011.

Warschauer, M., \& Meskill, C. 2000. Technology and second language learning. Retrieved from http://www.gse.uci.edu/ person/warschauer_m/tslt.html on 22nd May, 2011.

Waters, J. 2007. Curriculum Unbound. T. H. E. Journal, 34, 40-48. Retrieved from http://en.wikibooks.org/wiki/Instructional Technology /Learning_Management_Systems_Benefits on $23^{\text {rd }}$ March, 2011. 